\title{
Fusing East and West Leads a Way to Global Competitiveness in Emerging Economy: Lessons from China's Leap in Wind Energy Development
}

\author{
Narasimalu Srikanth \\ Energy Research Institute, Nanyang Technological University, Singapore.
}

\section{Chihiro Watanabe}

Tokyo Seitoku University, Japan and University of Jyvaskyla, Finland.

\begin{abstract}
China has demonstrated world leading wind energy development in the last five years which can be attributed to the fusion between its design and manufacturing strength in indigenous wind turbine industry and newly emerging wind energy industry in absorption of global best practices.

An empirical analysis of China's wind energy development trajectory over the last decade focusing on the technology sourcing from foreign firms in support of domestic players for accelerating functionality development through enhanced knowledge identification, absorption, assimilation and acclimatization was attempted.

Important lessons learned include (i) importance of supply chain in the technology diffusion, (ii) effective technology acquisition and assimilation through early domestic firm engagement, (iii) effect of relevant domestic firms involvement in technology transfer partnership to induce inter-industry spillovers, and (iv) a framework for an emerging nation to develop new functionalities.

Similarity and disparity with similar success of fusion in solar industry (JTMGE 3, 2) were also identified.
\end{abstract}

Keywords: China's wind energy, wind turbine industry, fusion, acclimatization, supply chain.

\section{INTRODUCTION}

Chinese policies have been praised by the world community including the Europe and USA, mainly the implications of the Chinese twelfth five year plan for the global race towards low carbon technology competiveness (IEA, 2013; REN21, 2010; Wharton, 2011; Worldbank, 2013). For example, after the renewable energy law was passed in 2005 (NREL, 2009), the total adoption of wind energy has reached $90 \mathrm{GW}$ by $2013^{1}$. This has been supported by conspicuous domestic production capacity that has been moving towards indigenization with least import of components. In addition, it was achieved through Chinese government's catalytic role in inducing stimulation through right policies such as renewable energy law in 2005 and setting sincere targets such as 15\% renewables by 2015 (APERC, 2009) (see Fig 1). For example, in

Journal of Technology Management for Growing Economies

Vol. 5 No. 2

October 2014 pp. 7-32

\section{CHITKARA 司 UNIVERSITY}

(C)2014 by Chitkara University. All Rights Reserved. 
Srikanth, N.

Watanabe, $\mathrm{C}$.

wind energy it is focused to achieve at least $100 \mathrm{GW}$ of wind energy by 2015 and with its accelerated pace it may reach the target much earlier (Figure 1).

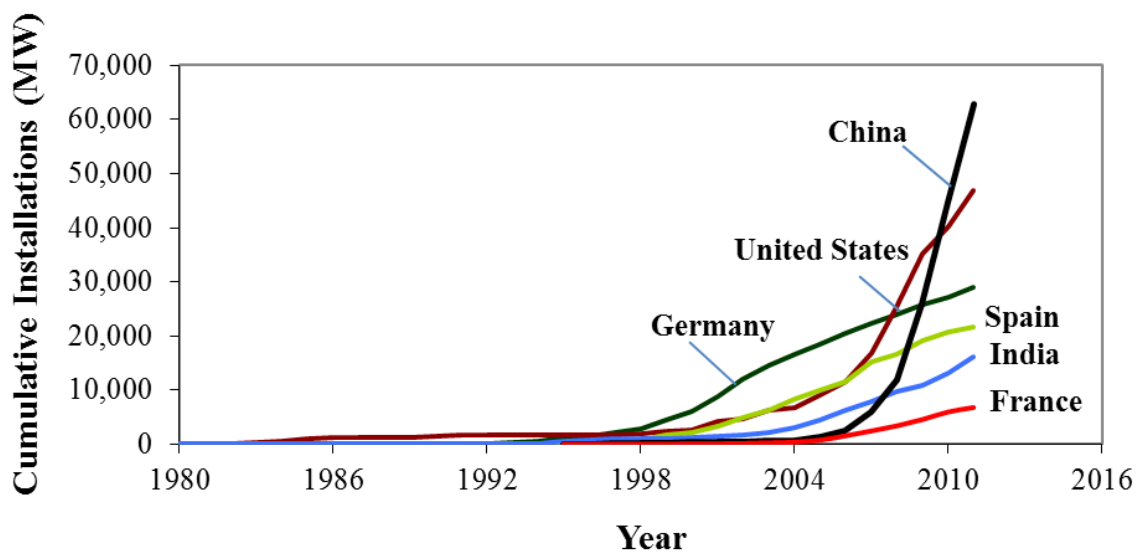

Figure 1: Cumulative installation of wind turbine in different countries (1980-2011)

Source: EPI (2012), GWEC (2013).

What interests the research community is in understanding the underlying mechanisms and working methods behind such catalytic role of government to achieve such goals as an emerging nation compared to its policies in the year 2000 (Sinton and Frindley, 2000). Hence, this forms the focus of the present research. One observation is that China has setup a virtuous cycle between assimilation capacity increase and acceleration in the emergence of the functionality development ${ }^{2}$ (Watanabe, 2009). Since its opening its domestic market in the 1980s, China has been constantly investing its research and development up to 2\% of the GDP (Buijs, 2011; ERI, 2009). This has helped in the growth of industrial enterprises, research institutes and higher educational institutes. Such institutes have been planned as clusters over the years that today China has more than 100 clusters spread across its 41 provinces with over 500 production centres, 30 university technology parks and 20 business foundation parks, etc. (Frost, 2010) that contribute towards significant manufacturing output at various levels viz., light, medium and heavy industry output.

Foregoing observation prompts us that China's recent renewable energy initiatives $^{3}$ (Bogaert, 2010; NREL, 2013) can largely be attributed to its conspicuous accomplishment in its renewable energy as follows-

(i) Renewable energy law in 2005,

Journal of Technology Management for Growing Economies, Volume 5, Number 2, October 2014 
(ii) Higher target of $15 \%$ renewable energy by 2015 ,

(iii) Insists in $90 \%$ domestic parts,

(iv) Support formation and navigate goals of industrial clusters, and

(v) Setting up consortia between academia and industries,

Such stimulants have helped to induce its industrial clusters towards assimilation of knowledge spillover from earlier foreign direct investment (FDI) and analyse relevance of earlier domestic innovations developed for other industries to transform towards new industry needs (Lorenzen, 2002; Lorenzen and Mahnke, 2002; Srikanth and Watanabe, 2012; You and Wilkinson, 1994). Partly these lie with the skilled labour trained in earlier industries with similar technologies. The result of such assimilation is in increasing the acceleration of production such that emergence of new functionality development has been observed. In the case of China's wind industry, such functionality development has been observed in terms of size of the wind turbines growing in geometric size as a consequence of sophisticated design, increased production and installation ability that has reached at the top level in the world..

Similar observation of industry evolution has been observed with China's solar industry, which confirms the fusing behaviour of the domestic firms with their know-how along with global free open access information such as patents and design standards in solar cell and module PV (Photovoltaic) manufacturing, which is due to knowledge spillover from relevant industries such as semiconductor and integrated circuit manufacturing industries (Srikanth and Watanabe, 2012). However the present case of study of China's wind industry differs in terms of additional effects of technology transfer and right government policies which was earlier studied through a cross-case analysis between the solar and wind industry of China (Srikanth and Watanabe, 2013). In the present study the industry and government's role in technology transfer, assimilation and innovation has been discussed in detail.

\section{China's conspicuous wind energy production}

China's wind turbine equipment manufacturing has industrialized rapidly since 2006 and has further matured towards delivering large turbines with international quality by 2009. During 2006, the government has set its policies towards a national goal of $10 \mathrm{GW}$ as an expectation by 2010 and this target drove the domestic turbine manufacturers to accelerate their industrial expansion for two years in succession and scale their products. By 2005, few Chinese domestic wind turbine manufacturers were existing, who had faced fierce market competition due to their production capacity and incompetent technology, which can be (quantified in terms of product size). They have

Journal of Technology Management for Growing Economies, Volume 5, Number 2, October 2014
Fusing East and

West Leads 
Srikanth, N.

Watanabe, $\mathrm{C}$.

grown significantly and by 2009 China had a total cumulative installed capacity of $25.8 \mathrm{GW}$ (GWEC, 2012; Junfeng, 2012), in terms of cumulative installed capacity, the top three, five and ten companies respectively accounted for $55 \%, 70 \%$ and $85 \%$ respectively.

The dominant turbine manufacturers, includes Goldwind (GW), Sinovel Wind Power (SI), Guodian United Power (UP) and Guangdong Mingyang (MY), have all established the necessary know-how to manufacture and have placed plants close to their regional wind farm customers. This reduces their transportation costs and ensures the timing of deliveries, which in turn had a positive influence on the development of the enterprise. In addition, regional governments motivated with supplemental policies to encourage the machine manufacturers to build plants in order to speed up the development of a local manufacturing industry and increase their tax revenues. Such local industrial support systems helped in the availability of human resources, supply chain formation and land resources to establish manufacturing bases.

Based on the basis of the foregoing observations, the present study focuses on understanding China's wind turbine industry technology sources knowledge assimilation methods. The study also investigates the related government's role in timely policy formulation towards evolving a new domestic wind industry that has exploited its own internal energy demands and met carbon emission reduction needs and arose new wind energy jobs for its people, through engaging its existing domestic manufacturing industries' capability and the country's own wind energy resource availability and transforming those into a useful production chain that met the country's clean energy market needs.

\section{ANALYTICAL FRAME WORK}

\section{Hypothetical Views}

China's wind energy industry has emerged and demonstrated conspicuous strength through developing indigenous product and supply and accelerating diffusion of wind energy to create a domestic market. Based on the foregoing observations, the following hypothesis is postulated-

(i) The conspicuous strength resulted from learning the technical knowhow and global best practices from foreign partners ("Global") through fusing with its domestic manufacturing industry's tacit knowledge and the intensive effort in learning, absorbing and assimilating from global partners ("Domestic") that lead to indigenous capabilities (technologies, human capabilities and increased product performance).

(ii) Exploring new solutions to support domestic wind industry needs was through joint work between domestic industry's intensive efforts in learning, absorbing and assimilating from global partners along with the 
government's catalytic role for the attainment of decarbonisation society for nation's sustainability.

(iii) The dynamic relationship between innovation and institutional factors that helped to achieve the wind energy adoption and domestic market creation and further supporting through indigenous wind turbine production is the essence of co-evolutionary acclimatization stage, which is the final stage of the growth framework.

\section{Literature review}

Innovation is costly, risky and path dependent. Hence developing nations such as China and India have been lagging behind the developed nations during 1980s. However their recent economic progress through industrial development has interested the researchers.

Literature claims endogenous growth theory explains these emerging nations' performance much better than neoclassical growth theory. The former is efficient as it holds that economic growth is primarily due to endogenous factors and not external forces. Thus, it relates the R\&D activities and investments to human capital, innovation and knowledge as the significant contributors to the long run growth rate. Labour capital formation and technology creation are usually seen as increasing returns or atleast as lower bound of diminishing returns to capital (Lai et al., 2006). One of the two popular models is the investment based growth model, which portrays growth as associated to the positive externalities of accumulated physical and human capital (Romer, 1986; Romer 1987). The second popular model is the R\&D based growth model, which portrays the role of technological progress for the creation of economic good. Externalities are a source of increasing returns and productivity growth. In general endogenous growth theory has highlighted the understanding of technological investment, however previous works highlights that international technological spillovers are seldom modelled in the endogenous growth literature. Few researchers have shown exceptions viz., Grossman and Helpman (1991), Rivera-Batiz and Romer (1991), Keller (1996), Zucker et al (2004) and Aghion and Howitt (1998), who modelled trade liberalization and economic integration on domestic technological change. Technology spillovers arise between firms helping to produce positive effects (Anon, 1998; Griliches, 1998) and this arises because the firm cannot appropriate the returns associated with its R\&D capital (Shah, 1995).

Griliches (1998) noted that earlier methods of using case study approach which uses a cost-benefit approach to calculate social rates of returns or spillovers, may be useful for only successful industries. Empirical methods are also limited in arriving at production functions (primal approach) or at
Fusing East and West Leads 
Srikanth, N.

Watanabe, $\mathrm{C}$.

cost function (dual approach) (Mohnen, 1996). But, they fail in capturing the spillover effect on the productivity. There is a need to evolve a quantitative method to arise a measurement method to quantify how much knowledge is spillable? As these spillovers are from non-rival technology and that technology imitation and spillovers are costless, these models have yet not reached key policy implications for emerging nations, possibly due to lack of empirical support (Barro, 1991; Williamson, 1991).

Even though all countries may attempt towards technology transfer, yet their absorptive capacity becomes important and to further attract FDI and MNCs. It is generally assumed by FDI literature that technology transfer takes place seamlessly between a developed region to a developing region and the host knowledge is generally ignored. Borensztein et al (1988) confirmed the importance of host country's absorptive capability from the labor stock's ability to absorb the spillover from foreign firms' technology. Lai et al (2006) studied 69 developed nations and showed the higher productivity of FDI holds only when the host country has a minimum threshold stock of labour force and the degree of openness on technology absorption. The higher of degree of openness enhances the imitation and learning capability from outside and it also enables the foreign firms to push the domestic firms' R\&D investment (Holmes and Schmitz, 2001). This study focuses on the literature gap to describe the relation between international technological spillovers, domestic technology absorptive capability, endogenous technological change and the steady state economic growth rate. Compared to the previous findings, the predictions in this study explain the emerging nations properly, The fusing of domestic industries capabilities and labor stock mobility has helped knowledge assimilation of global technologies to coevolve useful supply chain and market for wind turbines.

\section{Analytical framework}

\section{Analytical model development}

To understand the effective utilization of functionality development and increased productivity the analysis is performed through following steps-

(a) 'Cost of energy' (COE) is the key metric of renewable energy adoption to new region such as wind technology wherein its reduction helps to be price competitive with fossil fuel based energy. One approach is to exploit increasing returns through geometric scaling which can be seen as a form of functionality development (Srikanth and Funk, 2011). Thus, in this study, the effective adoption of increasing to geometric scale in Chinese wind turbines is investigated due to its potential to reduce COE and enhanced resource utilization (land, grid, etc.) (Srikanth and Funk, 2011).

Journal of Technology Management for Growing Economies, Volume 5, Number 2, October 2014 
(b) The assimilation ability of domestic firms is investigated by knowledge stock creation such as patents.

Fusing East and

West Leads

(c) The evidence of spillover from global to local firms is studied through investigating the contribution of global input into domestic firms' production function.

(d) The accumulation of such spillover in to industrial clusters is studied in terms of technological progress (Porter, 1998).

Accordingly, knowledge spillover from foreign to domestic firms and their assimilation ability of the domestic firms are studied in terms of the productivity enhancement and discussed in the following sections.

(1) Learning and scaling of China indigenous wind turbines

Chinese wind turbine prices show a decreasing trend with cumulative capacity of production mainly due to the learning coefficient (Srikanth and Funk, 2011). Secondly, with increasing geometric size or product capability the price of the energy is expected to decrease due to increasing returns to geometric scaling (Srikanth and Funk, 2011). Increase in geometric scaling may face barriers from existing technology solutions and can become barriers to functionality development which forces migration towards new solutions that may come from other industries (Srikanth, 2008; Srikanth, 2011). Thirdly, to capture the incentives of government towards larger wind turbines, a mathematical model $\left(a+b\left(\Phi-\Phi_{s}\right)\right)$ is assumed to mimic the government subsidy, where $a$ and $b$ are the constants, $\Phi$ is the turbine size in MW and $\Phi_{s}$ is the minimum peak capacity size of the wind turbine (quantified in megawatt (MW)) beyond which the subsidy is provided $(>2.5 \mathrm{MW})$. The reason being the government would motivate towards larger system to wisely use land resources and grid establishments. Thus, the price of the wind turbine capital cost can be expressed as a function-

$$
P(t)=F(\lambda(t), \Phi(t), G s(t))
$$

where $P(t)$ : cumulative installations of domestic wind turbine in MW,

$\lambda(t)$ : dynamic learning coefficient (please refer appendix),

$\Phi(t)$ : physical size of domestic turbines, and

$G s(t)$ : government subsidy approximated as:

$$
\left(a+b\left(\Phi(t)-\Phi_{s}\right)\right)
$$

$a, b$ : coefficients, and 
Srikanth, N.

Watanabe, $\mathrm{C}$.

$\Phi_{s}$ : threshold size beyond which incentives are provided by government. Equation (1) can be developed as follows-

$$
\ln P(t)=A+B \ln (\lambda(t))+C \ln (\Phi(t))+D \ln (G s(t))
$$

where, $A, B, C$ and $D$ are coefficients.

\section{(2) Assimilation ability of domestic firms}

The increase in the market share is due to the product size which can be shown to have arisen from the tacit and explicit knowledge of the domestic firm's knowhow and the explicit knowledge from the technology transfer and accessing the open technology such as patents of the global wind turbine gearbox that are accessible to the domestic firms. The domestic know-how depends directly on the skilled people's personal knowledge which can be related to the number of inventors of the domestic gearbox patents. This happens when the work force get trained in domestic firm of an existing industry within the region and shifts to a new upcoming firm of the new industry in the region for increased personal rewards and career growth, thereby becoming the knowledge carriers to bring new skills into the new industry and helping to assimilating and internalizing the external knowledge of the new budding industry with their personal tacit knowledge and further externalizing into new indigenous products for the firm. The present study extends the previous approaches (Cohen and Levinthal, 1989; Watanabe, 2009), based on the present observations of China's wind industry that a firm makes effort to maximize the contribution of assimilated technology spillover to the production by embodying it into the manufacturing processes.

Given that wind production $(W)$ is governed by the labour and capital resources $(X)$, and the gross technology stock of the domestic wind turbine industry (WT). The function is be depicted as follows-

$$
W=F(X, W T)
$$

Furthermore, since advanced wind turbines are technically driven, $W$ can be approximated as follows-

$$
W \approx F(W T)
$$

Thus under a technology driven condition-

$$
\ln (W)=c+d \ln (W T)
$$

where $\mathrm{c}$ and $\mathrm{d}$ are coefficients.

Since there should be no substantial difference with respect to assimilation $(z)$ of foreign wind patent and similar technology class domestic patents of the

Journal of Technology Management for Growing Economies, Volume 5, Number 2, October 2014 
domestic firms, the gross wind technology stock $(W T)$ can be depicted as-

$$
W T=T_{i}+z(F W P+D P)
$$

where, $T_{i}$ indigenous technology stock, FWP: foreign wind patent stock, and $D P$ : domestic wind patent stock.

For advanced products such as large scale wind turbines, the product size is proportional to the internal technology stock of the firm consisting of the explicit knowledge such as patents, standards, trade secrets, design guidelines and tacit knowledge of people. Thus, the level of indigenous stock $T_{i}$ at time $t$ can be approximated as a linear relationship between the technology stock and product size $\Phi_{i}$ is assumed as follows-

$$
\operatorname{Ti}(t) \approx m \Phi_{i}(t)
$$

where, $m$ : coefficient. Substituting equation (8) for $T_{i}$ into equation (7) and then substituting equation (7) for $W T$ into equation (6) to determine $W$ shows-

$$
\begin{aligned}
& \ln (W)=c+d \ln \left(T_{i}+z(F W P+D P)\right) \\
& =c+d \ln \left(m \Phi_{i}+z(F W P+D P)\right) \\
& =c+d \ln \left(m \Phi_{i}\right)(1+z(F W P+D P)) \\
& =c+d \ln \left(m \Phi_{i}\right)+d \ln \left(1+z(F W P+D P) /\left(m \Phi_{i}\right)\right)
\end{aligned}
$$

Since, $z(F w P+D P) /\left(\left(m \Phi_{i}\right)<<1\right.$, equation (9d) can be approximated as follows-

$$
\begin{aligned}
& \ln (W) \approx c+d \ln \left(m \Phi_{i}\right)+d z\left((F W P+D P) /\left(m \Phi_{i}\right)\right) \\
& \equiv c+d \ln \left(m \Phi_{i}\right)+e\left((F W P+D P) /\left(m \Phi_{i}\right)\right)
\end{aligned}
$$

where $e=d z$. Thus, taking the ratio of coefficient of second and third term, the domestic wind turbines firms' assimilation value $z$ of using foreign wind firms' patents with know-how of domestic industries can be identified by the following equation-

$$
z=(e / d)
$$

(3) Spillover effect from foreign invested firms to private firms

In order to evidence the technology spill over from foreign firms in to domestic firms the various factors of firms productivity apart from its labor and capital investment, can be investigated. In this study, the total factor productivity of foreign firms was taken as an indicator of the technology stock of the foreign firms tocheck the spillover effect on domestic firm's production function.

Journal of Technology Management for Growing Economies, Volume 5, Number 2, October 2014 
Srikanth, N.

Watanabe, $\mathrm{C}$.
The inter-dependency of foreign firms' technology stock on the domestic (also called private) firms productivity can be studied by grouping the private firms specific to machinery and accounting the spillover of the foreign firms' technology stock on domestic firms. One method is to compute the independent technology productivity function of the foreign firm as follows:

$$
Y_{F}=A_{F} L_{F, j}^{\alpha_{F}} K_{F, j}^{\beta_{F}}
$$

where

$Y_{F}$ : foreign firms' production,

$A_{F}:$ scale factor,

$\alpha_{F}, \beta_{F}:$ coefficients,

$j$ : specific sector of industries,

$L_{F}$ : foreign firms' labour stock, and

$L_{F}$ : foreign firms' capital stock

Taking logarithmic form and computing the total factor productivity (TFP) for different industries, we get-

$$
\ln \left(T F P_{F, j}\right)=\ln \left(Y_{F, j}\right)-\alpha_{F} \ln \left(L_{F, j}\right)-\beta_{F} \ln \left(K_{F, j}\right)
$$

where, $T F P_{F, j}$ : total factor productivity of $j$ th sector of industries.

Given that the domestic private firms utilize TFP spillover from foreign firms by assimilating it, the productivity function of the domestic private firms can be computed by accounting the foreign firms' technology stock of same type of industrial sector as follows-

where,

$$
Y_{P}=A_{P} L_{P, j}^{\alpha_{P}} K_{P, j}^{\beta_{P}} T F P_{F, j}^{\gamma_{P}}
$$

$Y_{P}:$ domestic private firms' production,

$A_{P}:$ scale factor, and

$$
\alpha_{P}, \beta_{P}, \gamma_{P}: \text { coefficients, }
$$

Expressing in logarithmic form-

$$
\ln \left(Y_{P}\right)=\ln \left(A_{F}\right)+\alpha_{P} \ln \left(L_{P, j}\right)+\beta_{P} \ln \left(K_{P, j}\right)+\gamma_{P} \ln \left(T F P_{F, j}\right)
$$

(4) Effect of technological progress of clusters growth

In order to evidence the technology accumulation of the domestic firms in the regional clusters the total factor productivity can be investigated. Accordingly, 
the gross production value of the heavy industries of different region in China can be depicted as a function of the employees and total capital assets as follows-

$$
Y_{i}=F\left(L_{i}, K_{i}\right)
$$

where subscript ' $i$ ': indicates region.

Expressing in Cobb-Douglas type production function and taking logarithm, total factor productivity (TFP) can be predicted as follows-

$$
\ln \left(T F P_{i}\right)=\ln \left(Y_{i}\right)-\alpha \ln \left(L_{i}\right)-\beta \ln \left(K_{i}\right)
$$

where $\alpha, \beta$ : coefficients.

\section{Data Construction}

The patents of the wind turbines gearbox was obtained and classified based on their technology class. This helped to identify the key technologies to design and build wind turbine filed by the dominant MNC firms that were obtained by searching the Thomson database. The available know-how in the domestic firms of China was identified by taking the patents originated in other industries of China (such as shipping, automotive and oil rigs) and similarly classified to identify the key technology classes. The patent count signifies the quantum of knowledge available in each technology class. In addition, the number of inventors in each technology class was identified, as these are the key knowledge transporters between industries. The data concerning market share, turbine capacity and number of turbines of the domestic and foreign turbine manufacturers' installation share was obtained from China Wind Energy Association ${ }^{4}$ (CWEA, 2014) and its official website and annual reports of the wind turbine firms.

Turbine list prices of 255 turbine models for 1991-2003 was obtained from the data compiled by Junginger (2002) that was adjusted using 2003 GDP deflator (Worldbank, 2014) with proper exchange rates of Euro as per 2001. Policy details were obtained from Chinese wind industry report and interviews with wind turbine manufacturers.

\section{RESULTS}

\section{Empirical Findings}

(1) Effects of learning, scaling and government subsidies.

Utilizing backward elimination method (BEM) with $1 \%$ statistical significance

Journal of Technology Management for Growing Economies, Volume 5, Number 2, October 2014 
Srikanth, N.

Watanabe, $\mathrm{C}$.

level, the learning coefficient of the domestic wind turbine manufacturing firm as shown in Fig. 2 was found to be:

$$
\begin{gathered}
\lambda(t)=\left(+0.098+0.058 t-0.005 t^{2}+7.780(10)^{-6} t^{4}\right) \\
(5.22)^{* * *}(24.78)^{* * *}(33.64)^{* * *}(33.26)^{* * *}
\end{gathered}
$$

*** Significance at the $1 \%$ level. $\quad$ adj. $\mathrm{R}^{2}=0.997$

Thus, the relationship between price to learning, scaling and government subsidy of China's domestic wind turbine manufacturers is as follows:

$$
\begin{aligned}
\ln (P(t))= & 3.767-0.244 \ln (\lambda(t))-0.352 \ln (\Phi(t))-0.152 \ln (G s(t)) \\
& (7.57)^{* * *}(-3.56)^{* * *} \quad(-7.04)^{* * *} \quad(2.31)^{* * *}
\end{aligned}
$$

*** Significance at the $1 \%$ level. adj. $\mathrm{R}^{2}=0.893$

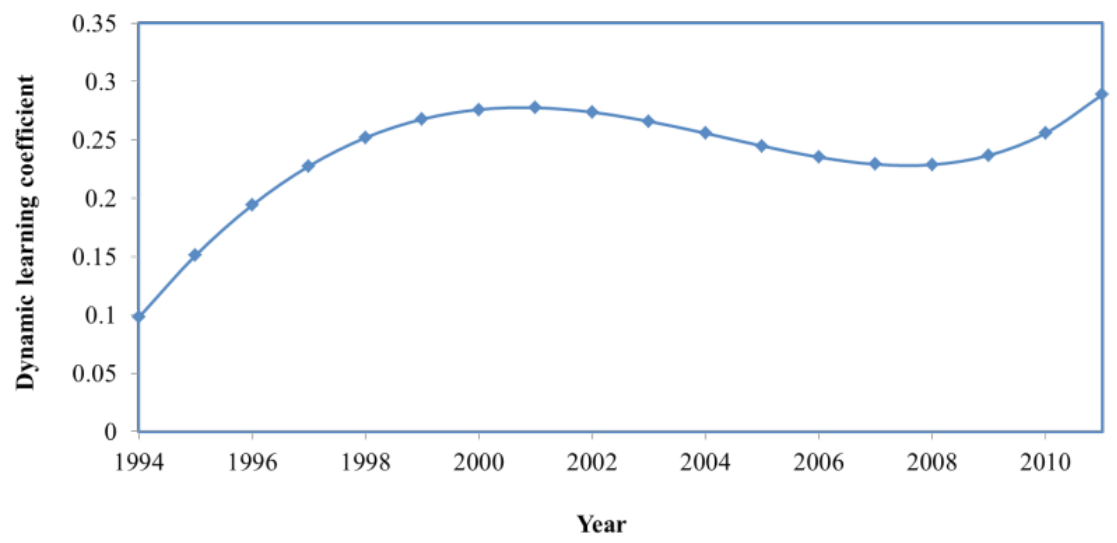

Figure 2: Dynamic learning curve of China's wind turbine manufacturing firms

(2) Assimilation capability of China domestic wind turbine firms

From equation (9f) the relation of scaling $\Phi(t)$ to the wind turbine production $\mathrm{W}(t)$ can be identified as follows:

$$
\begin{aligned}
\ln (W(t))= & -13.297+2.370 \ln (\Phi(t))+0.673((F W P(t)+D P(t)) / \Phi(t)) \\
& (-12.30)^{* * *}(6.50)^{* * *} \quad(8.85)^{* * *}
\end{aligned}
$$

*** Significance at the $1 \%$ level. adj. $\mathrm{R}^{2}=0.926$

From equation (10) assimilation capability ' $z$ ' can be identified as follows: 


$$
z=(0.673 / 2.370)=0.29
$$

Fusing East and West Leads

(3) Spillover effect from foreign direct investment to private firms

The increasing productivity of hi-technology products from domestic firmsas shown in Figure 3 with world class features are evidences of the assimilation capability derived from the foreign firms' know-how and mobility of labor stock from foreign firms to domestic firms. In the earlier study on solar industry (Srikanth and Watanabe, 2012) patents analysis results showed the assimilation capability of wisely fusing the external know-how with domestic know-how of similar technology class to the new industry need, which demonstrates the searching, absorbing, assimilating and transforming skills of the domestic work force.

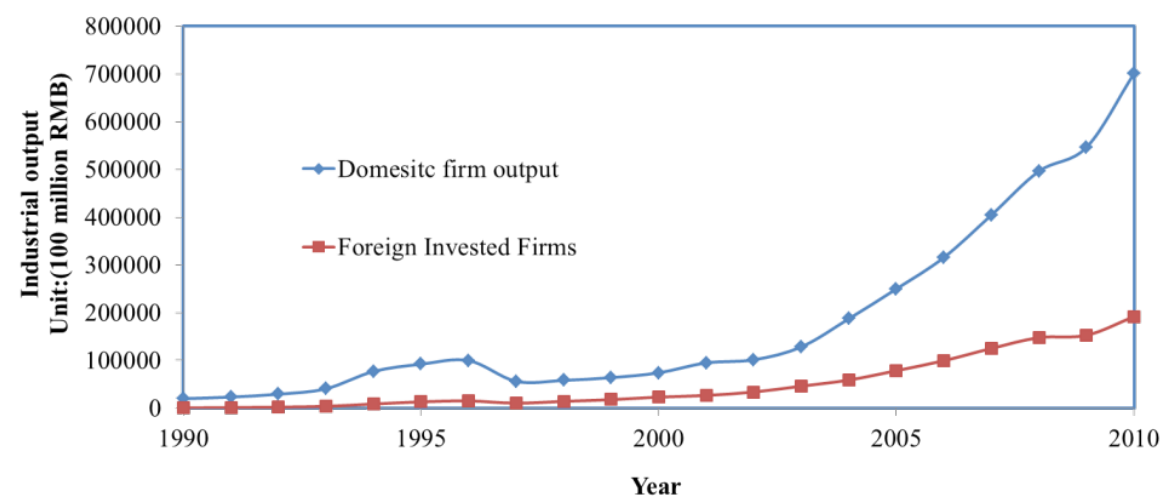

Figure 3: Industrial output trend in domestic firms versus foreign invested firms $\left(1990-2010^{5}\right)$. (CDO, 2013).

The present empirical analysis showed the production function of the private firms with respect to 100 heavy industrial products. It shows interdependency of the foreign firms' technology effects based on equation (14) and is found to be:

$$
\begin{aligned}
& \ln \left(Y_{P}\right)= 3.837+0.686 \ln \left(L_{P, j}\right)+0.332 \ln \left(K_{P, j}\right)+0.479 \ln \left(T F P_{F, j}\right) \\
&(4.99)^{* * *}(5.91)^{* * *} \quad(2.79)^{* * *} \quad(3.60)^{* * *} \text { adj. } \mathrm{R}^{2}=0.990
\end{aligned}
$$

*** Significance at the $1 \%$ level.

From the above empirical finding, it is clear that the elasticity of productivity with foreign firms TFP which is identified as 0.479 , which clearly indicates that the foreign firm's technology stock contributes to the domestic firm's 
Srikanth, N.

Watanabe, $\mathrm{C}$. productivity, through technology spillover and labour mobility.

(4) Effect of clusters' technological progress

The production function for different region's industrial sector, illustrated in Figure $4(\mathrm{a})$ is given by:

$$
\ln \left(Y_{i}\right)=6.041+0.584 \ln \left(L_{i}\right)+0.586 \ln \left(K_{i}\right)
$$

*** Significance at the $1 \%$ level.

The TFP was computed for various industrial cluster regions within China based on equation (16) and is demonstrated in Figure 4(b).
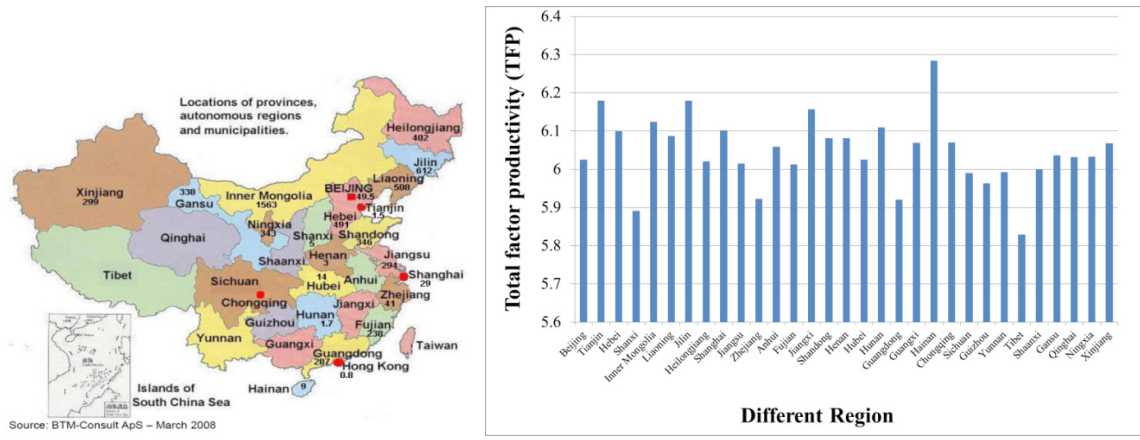

Figure 4: (a) Different regions of China taken for analysis (Source: CDO (2013) (b) Technological progress results of different region of China in heavy industry estimated from present study (2010).

The above regional performance of clusters in heavy industry matches well with the actual observation of wind industry manufacturing in Hebei, Inner Mongolia and Tianjin. The Tianjin industrial cluster is from the development of state owned enterprises which acts as foundation to cooperate with foreign companies, together to lower costs and improve market reaction so as to become competitive worldwide. It has a large number of existing trained skilled industrial technical workers to suit heavy industry and has more than 850 wind power manufacturers and suppliers, including domestic and foreign firms. Total investment of 12.645 billion Yuan and a total workforce of 24,760, have formed the most complete system in China's wind power industry. Its annual capacity is $5600 \mathrm{MW}$ of turbines that encompasses generator, blade and gearbox skills. 
In order to establish themselves in Tianjin cluster during 2005, success lured foreign firms such as Vestas, had setup a factory with a 363 million USD making it an important manufacturing base in China. Choice of selection of this cluster was due to its location and infrastructure (Perrot and Filippov, 2010). As of now, it has developed a strong value chain with 80 odd local suppliers. Spain-based Gamesa Corporation and Indiabased Suzlon Energy have followed suit of such investment in Tianjin. In 2009, Vestas started core technology components (control systems, and precision components) and introduced new product V60-800KW model that was designed for China's terrain and was locally produced in the Tianjin region, which also met China's domestic content policy requirement.

\section{DISCUSSION}

The current thinking of technology transfer in published foreign direct investment (FDI) literature assumes that when a technology is provided to a region it easily absorbs and starts production without further support. However, with every technology there is a tacit part of the knowledge that cannot be codified which is generally termed as personal knowledge (Nonaka and Toyama, 2003). Researchers have proved that it can be imparted only through 'learning by doing' such as training or hands-on work. In practise it can be accelerated if the work force arrives from a related technology domain from another firm with necessary technical skills.Economists have often contended that technology transfer will suffice economic growth and new industry evolution. In the present study, a new metric of assimilation is introduced and the evidence of assimilation is shown to be positive with a magnitude of 0.29 out of 1.0 (see equation 20). It is an evidence of technology assimilation ability by today's Chinese domestic wind turbine firms through absorption from external know-how and recombining and recreating with their intrinsic resources in tune to the regional market demands.

Griliches (1992) contends firms' level of technology knowledge depends not only on internal R\&D investment, but also on the knowledge stock developed by other firms or industries. These external effects are referred to as technology spillover. This spillover is enhanced when the firm is within an industrial cluster, which exploits existing agglomeration. In this study, the idea pursued is that the overall productivity effects of FDI of a new industry may depend on the firms of pre-existing industries. In examining the productivity impacts of foreign owned transnational

Journal of Technology Management for Growing Economies, Volume 5, Number 2, October 2014
Fusing East and

West Leads 
Srikanth, N.

Watanabe, $\mathrm{C}$. corporations, this study focuses on China's growth in the new industries such as wind industry and investigate why it greatly differs from other underdeveloped country's industry growth or its own underdeveloped period (such as China's industries before reformation during 1990s). Accordingly, following research questions arise. First, does the new industry growth depend on the productivity spillover effects from previous similar industries? Second, does FDI within an industry is a good metric to show the presence of an active industry on which a newcomer industry can thrive. Studies by Liu et al (2000) and Buckley et al $(2002,2003)$ showed knowledge spillover scenario at the industry level at a certain snapshot. Previous studies focused on the impact of FDI on domestic firms' productivity and knowledge assimilation alone. A distinctive feature of the present research as shown in equation (21) is that it examines the relationship between the growth of an evolving industry and pre-existing industries in a region and further examines the impact of inward FDI on overall productivity for industry specific effects. This study shows the elasticity of domestic firms' productivity due to foreign firms TFP at a magnitude of 0.479 , which clearly indicates that the foreign firm's technology stock contributes directly to the domestic firm's productivity, through technology spillover and labour mobility.

China adopted wind turbines during a stage when the wind turbine technology was externally available as a dominant technology in the western world. For example, China focused on three bladed horizontal axis product architecture in wind turbines industry, which was a matured technology from the developed nations. Hence, the product innovation was quite matured and available for technology licensing from multinational firms (see figure 5) and thus helped certainty in investment and technology through assimilation from spillovers of global industries. In addition, China had much relevant external know-how opportunities for direct knowledge transfer through joint ventures and collaboration and to promote learning from free-open sources such as patents, and technical standards and academic publications when it decided to adopt and domesticate these technologies as illustrated in figure 6. Moreover, the steady growth of functionality development through the domestic firms is a further evidence of the domestic firms' assimilation and recreation ability as seen from figure 7 . 


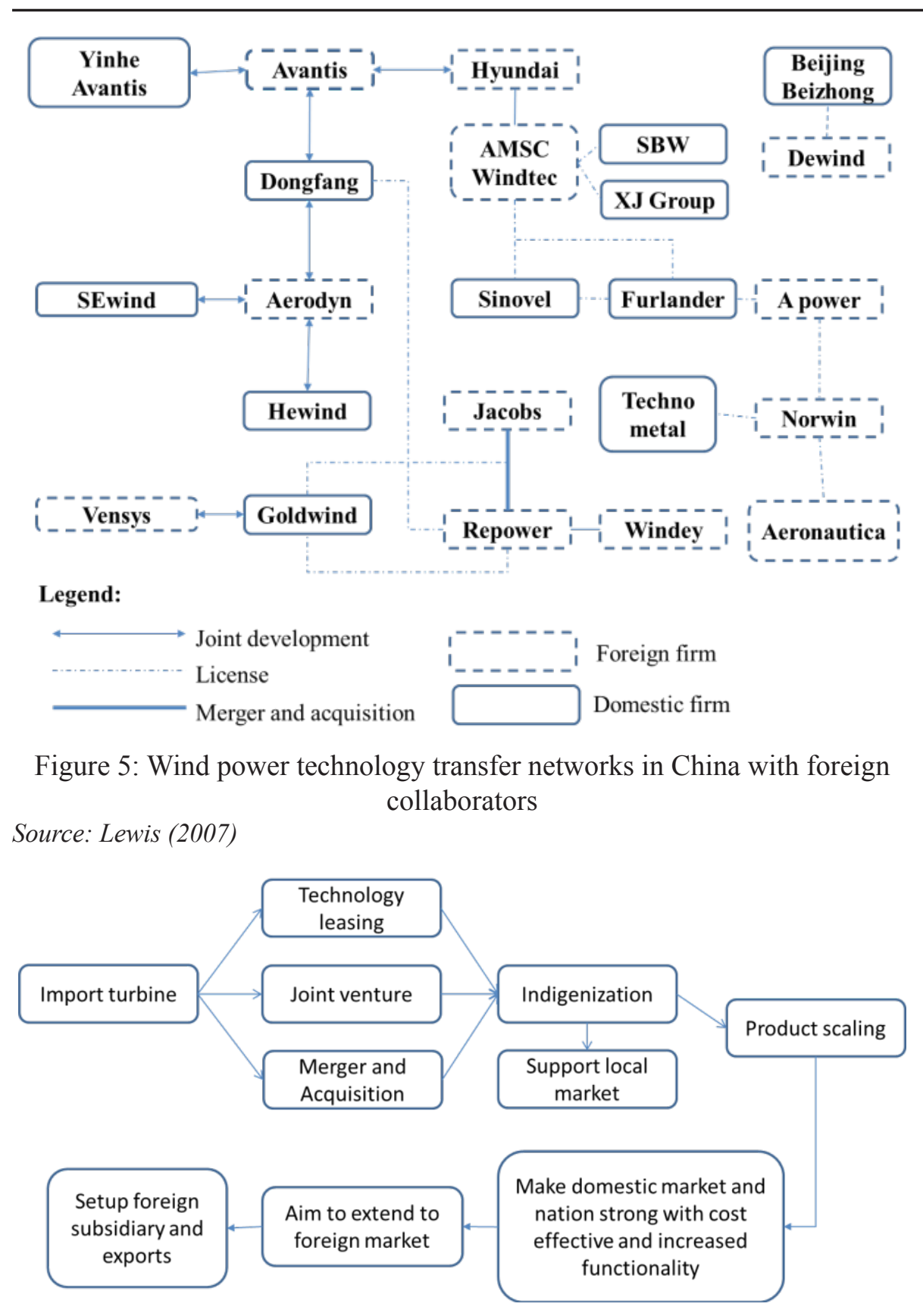

Figure 6: China wind industry technology acquisition route and its internalization, and indigenization and evolve markets. 
Srikanth, N.

Watanabe, $\mathrm{C}$.

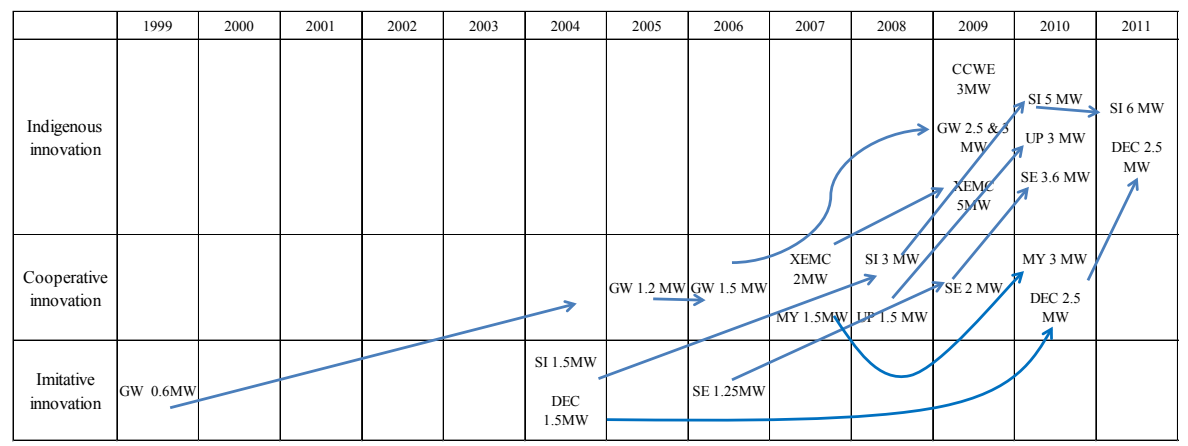

Figure 7: Transition of innovation modes of China's domestic windfirms $(1994-2011)^{a}$.

${ }^{a}$ Abbreviations SI: Sinovel, GW: Xinjiang Goldwind Science and Technology, DEC: Dongfang turbine, UP: Guodian united power technology, MY: China mingyang wind power group, SE: Shanghai electric group, XEMC: XEMC windpower and CCWE: China creative wind energy.

Source: Data from Ru et al (2012)

Growth theory has consistently linked technology improvement and long run growth (Aghion et al., 1998) have focused on the need of total factor productivity to the introduction of improved stock of technology in the country and the subsequent improvement of firms' revenue (Griliches, 1998). Earlier studies have also shown the importance of domestic industries in supporting the growth (Est, 1999; Jacobsson and Johnson, 2000) by highlighting that a country evolves an industry to support its own economic and social agenda through its own home market (Connor, 2004). However, they didn't explain in detail the mechanism to co-evolve a regional market and the means to exploit the relevant know-how of the domestic firms through relevant policies and institutional innovation, which forms the core part of this research. The present study has shown the importance of the local know-how and the means to creation of market and supply chain through domestic firms' involvement through assimilation of the external technology transferred using domestic skilled labor and local firms of similar industries to create the necessary production chainand indigenous creation of relevant products for domestic market needs.

Foreign affiliates are generally seen to exhibit higher levels of productivity than local firms (Aitken and Harrison, 1999), which is due to the firm specific assets of transnational corporations (TNCs) which account for increase in productivity in FDI receiving firms (Egger and Pfaffermayr, 2001). In addition, empirical research shows foreign equity participation outperform firms that are locally owned (Blomstrom and Sjoholm, 1999). The second influence of FDI arises in terms of knowledge and/or productivity spillover to the host country's home grown firms (Aitken and Harrison, 1999; Buckley et al., 2002), but their 
reasons are not still well investigated. However, in emerging regions there is a predominant scepticism to globalization due to rising fear of job scarcity domestic industries will perform poorly (especially in the government sector). This has been attributed to the opening up of economy and infusing FDI into the country (Deepti, 2011). Hence, the domestic firms and skilled labor in any emerging nation generally resort to object to government's globalization plans. On the contrary, the findings of the present study show that the early involvement of domestic firms in technology transfer helps (a) to assimilate and fuse foreign MNCs technology with domestic know-how and coevolving domestic market for these products (b) helps to enhance the R\&D spillover and the growth of the local industry. This will help in improving energy sufficiency to meet economic demands, increased economic growth \& foreign exchange, meet clean energy adoption demands of the nation and further help to increase jobs and energy per capita for people's needs, along with further support to the region through customized product design (OECD, 1998).

Technology transfer as a form of co-creation for future market creation is discussed by Rai et al (2010). The present study elucidated an elegant approach in the form of co-creation model, which can thus be generalized as a framework for emerging economies (see Figure 8). The emerging region can co-evolve the market and production through a two-pronged approach. It could identify its market needs to attract foreign players. Further it could initially choose any of the technology transfer models as an initial part of their technology roadmap and leverage domestic industry know-how to enhance assimilation, absorption and recreation by fusing with existing technology spillover and evolve production value chain from its related domestic industry to build their own competitive strengths and adapt technology for localization. Thus government policy and the co-creation of the required institutions become important to aid the diffusion of the foreign knowledge from established technology developers. Further they could setup as industrial clusters to aid agglomeration of know-how from existing established domestic industries to support spillover and assimilation of the technology transfer along with domestic know-how for a new evolving industry in the region. Thereby, firms involved in other industries with similar technology capabilities can widen their market by participating in the new industry and identify the domestic market and its social needs and evolve new products for commercialization. In parallel, firms with internal research department are to be embraced in the national innovation effort to assimilate knowledge spillover and global know-how to bring out their indigenous products to meet their market demand along with similar functionality development trajectories to compete with global players. These two mechanisms can work in tandem to support an aspiring emerging nation to meet its market demand.

Journal of Technology Management for Growing Economies, Volume 5, Number 2, October 2014
Fusing East and

West Leads 
Srikanth, N.

Watanabe, $\mathrm{C}$.

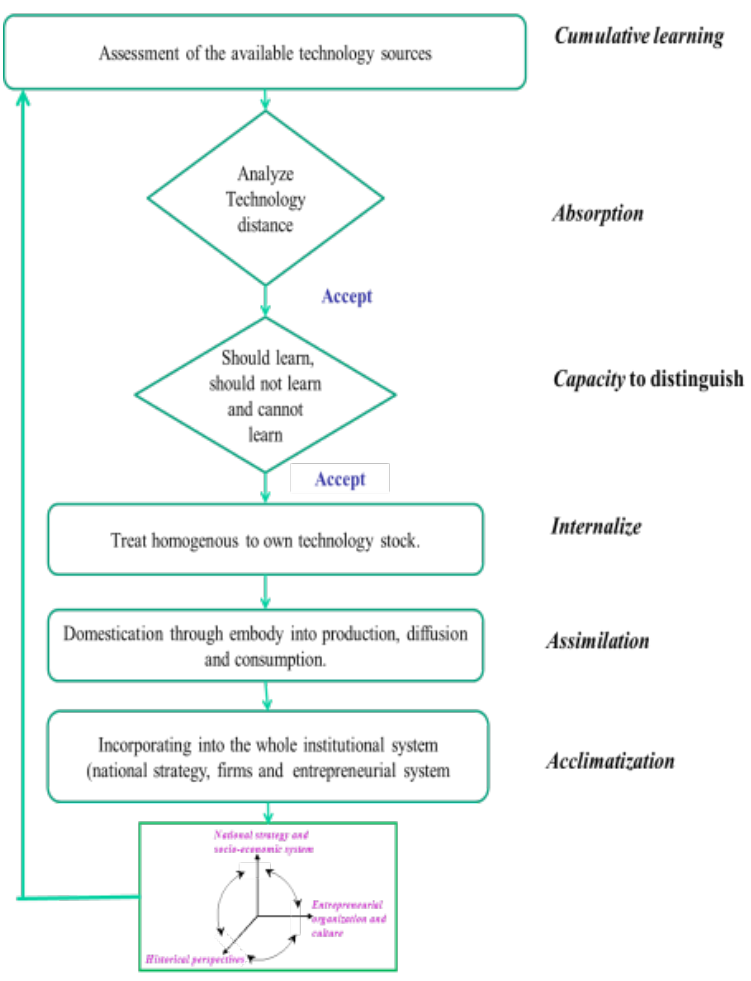

Figure 8.Present study's inference on China wind industry technology through a co-evolutionary acclimatization of external and internal knowledge in industry evolution.

Published literature has dealt well with globalization and its impact through foreign direct investment and technology transfer to an emerging nation's capability to enhance the manufacturing competence and to become a part of the global supply chain (Sonobe et al., 2002). These earlier studies ignored the impact of knowledge spillovers on the capability formation of the emerging nation. However, knowledge spillovers have substantial macroeconomic implications for growth and international trade (Romer, 1990). These implications result in $\mathrm{R} \& \mathrm{D}$ production and geographically localized knowledge spillovers, which were less studied in this context. Zucker et al (2004) showed R\&D spillovers as a major source of endogenous growth in recent "New Growth Theory" models (Zucker et al., 2004).

Positive spillovers are known to arise when the leading edge technologies of foreign MNCs influence and improve the productivity of locally owned firms (Feinberg and Majumdar, 2001). Negative effects (Aitken and Harrison, 1999) 
are known for specifically in pulling the demand from the home grown firms. These are in a context in which the locally originated firms within a closed economy tend to have weak technological capabilities. Such deficiencies will disable them to appreciate the value of externally generated knowledge and restrict their absorptive capability to intake the knowledge spillovers by foreign spillovers (OECD, 2009). Thus, positive spillovers may primarily occur from "demonstration effect", "contagion effects", people movements, and through pro-competitive effects. In addition, it is seen that locally owned firms are concentrated in the standard technologies where the foreign firms avoid.

Few studies have focused to articulate that the mechanism of industrial development through interdepencies (Puga and Venables, 1998; RodriquesClare, 1996). They showed that in a monopolistic competitive market the cost reduces by increasing competition among the local players and that the benefits of decreased cost are passed to the downstream firms. However in this study, the idea that knowledge workers transmit knowledge across sectors is found plausible empirically. Hence, a complementary process may arise such that if new industries develop, they exploit the knowledge brought by the workers from similar technology relevant industries and thereby increase assimilation, absorption and recreation capability of the recipient industry. The present study results shows the global know-how, which a firm in the emerging region can access from the pre-existing regional firms of other industries and/or the global know-how such as the free access of the international patent database and academic publications can be of great support in the knowledge development of the firms. Secondly, a novel empirical indicator is introduced to quantify and monitor the evidence of such knowledge spillover and domestic industrial cluster's assimilation ability. The idea of open innovation has been discussed by Chesbrough (2003) which discusses the benefits of a firm to exploit the external know-how and resources. However this study further elucidated to evolve a modular supply chain that enhances the robustness of production supply to meet the market demand. The partners of the supply chain focus on their core strength and migrate to latest technology to support the new industry (e.g., the blade manufacturers migrate to latest process technology). This results in a competitive environment resulting in cost effective and high functionality production. The findings of this research has highlighted the idea of utilizing domestic firms in technology transfer mechanism, which results in enhanced assimilation of both tacit and explicit knowledge and also induce inter-industry technology spillover from domestic industries, induce cost competiveness by bringing relevant skilled labour stock and evolve early functionality development and thereby induce enhanced production and meet the nation's demands and move towards indigenization. 
Srikanth, N. CONCLUSION

Watanabe, C. The present study shows the conspicuous strength in wind turbine manufacturing and internal market development in recent years. Empirical analysis was conducted focusing on the interaction between indigenous manufacturing industry and newly emerging wind turbine manufacturing industry in absorption of global know-how thereby creating fusion between them to develop critical technologies such as large megawatt level gearbox for the wind industry.

(i) The industry evolution and useful supply chain can be attributed to a joint work between industry's technology transfer partnership and exploiting existing know-how of related industry to explore new business,

(ii) Internal market demand contributes significantly to indigenization and thus an increase in technology stock by assimilation capability,

(iii) The set of leading domestic wind turbine manufacturing firms shows the evidence of positive knowledge spillage from the existing manufacturing industry,

(iv) A new way of identifying the technology spillover to evolve a new product from existing sources using patent technology class was demonstrated.

(v) Existing industry's exploitation of know-how minimizes the barriers to technology adoption.

(vi) Government's catalytic role in supporting local manufacturing industry through evolving new industries and supporting through domestic market has been successful in evolving the conspicuous strength.

(vii) The evidence demonstrates the possibility that emerging economies can co-develop the internal demand for a product and its supply chain concurrently thereby it benefits by moving towards indigenization and sustained growth of the country.

\section{ENDNOTE}

1. http://cleantechnica.com/2014/02/06/2013-wind-energy-installationsstall-u-s-surge-china/

2. Functionality development may imply: "Ability to improve performance of production processes, goods and services by means of innovation" (Watanabe, 2009).

3. http://www.nrel.gov/docs/fy04osti/35786.pdf

4. CWEA (2014), China wind energy association, http://www.cwea.org.cn/, accessed on 16/11/2014.

5. CDO (2013), China data online, http://chinadataonline.org/service/, accessed on $30 / 10 / 2013$.

Journal of Technology Management for Growing Economies, Volume 5, Number 2, October 2014 


\section{REFERENCES}

Aghion, P., and Howitt, P. (1998) 'Endogenous Growth Theory', Cambridge, MA: MIT press.

Aitken, B.J. and Harrison, A. E. (1999) 'Do domestic firms benefit from direct foreign investment? Evidence from Venezuela', American Economic Review, 89:3, pp. 605-618.

Anon (1998) Analytical report on technology, productivity and Job Creation, Best policy practices, OECD, Paris.

APERC (2009) Understanding Energy in China Geographies of Energy Efficiency, Tokyo

Barro, R. J. (1991) Economic Growth in a Cross Section of Countries, NBER Working Papers 3120, National Bureau of Economic Research, Inc.

Blomström, M and Sjöholm, F. (1999) 'Technology transfer and spillovers: Does local participation with multinationals matter?', European Economic Review, 43:4-6, pp. 915923.

Bogaert, B. (2010) Renewable Energy in China: An Analysis of Policy Instruments, Master thesis, 2010.

Borensztein, E., De Gregorio, J. and Lee, J-W. (1998) 'How does foreign direct investment affect economic growth?', Journal of International Economics, 45:1, pp. 115-135.

Buckley, P., Clegg, J. and Wang, C. (2002) 'The impact of inward FDI on the performance of Chinese manufacturing firms.', Journal of International Business Studies, 33:4, pp. 637655.

Buckley, P., Clegg, J. and Wang, C. (2003) 'Is the relationship between inward FDI and spillovers linear? An empirical examination of the case of China', paper presented at the 29th Annual Conference of European Academy of International Business, 11-13 December, Copenhagen.

Buijs, B. (2011) 'Why china matters', in Sioshansi, F.P. (Eds) Energy Sustainability and the Environment: Technology, Incentives and Behavior, Elsevier, pp. 445 - 477.

CDO (2013) China data online,(online)(cited 30 Oct 2013). Available from <URL: http:// chinadataonline.org/service/>.

Chesbrough, H. W. (2003) 'Open innovation: the new imperative for creating and profiting from technology', Harvard Business School Press.

Cleantech (2014)(online) Availbale from: <URL:http://cleantechnica.com/2014/02/06/2013wind-energy-installations-stall-u-s-surge-china/ $>$.

Cohen, W. M. and Levinthal, D. A. (1989) 'Innovation and learning: The two faces of R\&D', The Economic Journal, 99:397, pp.569-596.

Connor, P.M. (2004) 'Renewable Electricity in the United Kingdom: Developing Policy in an Evolving Electricity Market', in De Lovinfosse I. and Louvain F (eds.), Renewable Electricity Policies in Europe: Tradable Green Certificates in Competitive Markets, Presses Universitaires de Louvain, pp.243-300.

CWEA (2014) China wind energy association, (online)(cited 16 Nov 2014). Available from $<$ URL:http://www.cwea.org.cn/>

Deepti (2011) 'Foreign direct investment in different sectors in Indian Economy', New Delhi. Deep and Deep Publications.

EPI (2012) 'Cumulative installation of wind turbine in different countries', Earth policy institute, (online) Available from $<$ URL:www.earth-policy.org

ERI (2009) 'The realization of energy conservation objective of '11th Five-year' in China: strategy and implementation', Beijing. Guangming Daily Publishing House.

Est, V. R. (1999) 'Winds of Change: A Comparative Study of the Politics of Wind Energy Innovation in California and Denmark', Utrecht. International Books.

Egger, P. and Pfaffermayr, M. (2001) 'A note on labour productivity and foreign inward direct investment', Applied Economics Letters, 8:4, pp. 229-232.

Feinberg, S.E. and Majumdar, S.K. (2001) 'Technology Spillovers from Foreign Direct Investment in the Indian Pharmaceutical Industry', Journal of International Business Studies, 32:3, pp 421-437.
Fusing East and

West Leads 
Srikanth, N.

Watanabe, $\mathrm{C}$.
Frost (2010) Economic 360 for China: Growth Prospects and Emerging Opportunities in the Manufacturing Industry, Report no. 4726-90.

Griliches, Z. (1992) 'The search of R\&D spillovers', Scandinavian Journal of Economics, Supplement, pp. 29-47.

Griliches, Z. (1998) ' $R \& D$ and productivity: The Econometric Evidence', Chicago, IL. The University of Chicago Press.

Grossman G., and Helpman, M. (1991) 'Trade, knowledge spillovers and growth', European Economic Review, 35:2-3, pp. 517-526.

GWEC (2012) Global wind energy council Country Report, (online) Available from < URL:http:// www.gwec.net/publications/country-reports/ china-wind-energy-outlook-2012>.

GWEC (2013) (online) (cited 30 Oct 2013) Available from <URL:www.gwec.net>.

Holmes, T. J. and Schmitz, J. A. (2001) 'Competition at work: Railroads vs. monopoly in the U.S. shipping industry’, Quarterly Review, 25:2, pp. 3-29.

IEA (2013)(online) (cited 6 March 2013) Available from <URL:www.iea.org/media/etp/ Tracking_Clean_Energy_Progress.pdf $>$

Jacobsson, S., and Johnson, A. (2000) 'The diffusion of renewable energy technology: an analytical framework and key issues for research', Energy Policy, 28:9, pp. 625-640.

Junfeng (2012) China wind energy outlook, 2012.

Junginger, H. M. (2002) 'Learning in Renewable Energy technology development', Copernicus Institute for sustainable development and innovation of Utrecht University.

Keller, W. (1996) 'Absorptive capacity: On the creation and acquisition of technology in development', Journal of Development Economics, 49:1, pp. 199-227.

Lai, M., Peng, S. and Bao, Q. (2006) 'Technology spillovers, absorptive capacity and economic growth', China Economic Review, 17:3, pp. 300-320.

Lewis, J.I. (2007) 'Technology Acquisition and Innovation in the Developing World: Wind Turbine Development in China and India', Studies in Comparative International Development, 42:3-4, pp. 208-232.

Liu, X., Siler, P., Wang, C. and Wei,Y. (2000) 'Productivity spillovers from foreign direct investment: evidence from UK industry level panel data', Journal of International Business Studies, 31:3, pp.407-425.

Lorenzen M. (2002) 'Ties, Trust, and Trade, Elements of a Theory of coordination in Industrial Clusters', International Studies of Management and Organization, 31:4, pp. 14 -34.

Lorenzen, M. and Mahnke, V. (2002) 'Global strategy and the acquisition of local knowledge: how MNC enter knowledge systems', Copenhagen Business School, Copenhagen.

Mohnen, P. (1996) 'R\&D externalities and productivity growth', in STI review no. 17, OECD, Paris, pp. 39-59.

Nonaka, I. and Toyama, R. (2003) 'The knowledge-creating theory revisited: knowledge creation as a synthesizing process', Knowledge Management Research \& Practice, 1:1, pp. $2-10$.

NREL (2013) (online) (Cited 3 March 2013)Available from <URL:http://www.nrel.gov/docs/ fy04osti/35786.pdf>.

OECD (1998) 'Analytial report on technology, productivity and Job Creation', Best policy practices, OECD, Paris, 1998.

OECD (2009) 'Foreign direct investment, absorptive capacity and regional innovation capabilities: evidence from China', (online) Available from <URL:www.oecd.org>

Perrot, R. and Filippov, S. (2010) 'Localization strategies of firms in wind energy technology development', Proceedings of 7 th International Conference on Innovation and Management, pp. 30-38.

Porter, M. (1998) 'The competitive advantage of nations: with a new introduction', New York. Free Press.

Puga, D. and Venables, A. J. (1998) 'Agglomeration and economic development: Import substitution vs. trade liberalization', London. Centre for Economic Performance.

Journal of Technology Management for Growing Economies, Volume 5, Number 2, October 2014 
Rai, S., Belle, J.,P.,V. and Pedersen, M., K. (2010) 'Technology transfer as a form of Co- Creation for Future Market Creation; issues, frames and concepts', Working Paper No. 05- 2010.

REN21 (2010) 'Renewables-2010, global status report', (online) Available from <URL:http:// ren21.net/>.

Rivera-Batiz, L. A. and Romer, P. M. (1991) 'Economic Integration and Endogenous Growth', Quarterly Journal of Economics, 106:2, pp. 531-555.

Rodríguez-Clare, A.(1996) 'Multinationals, Linkages and Economic Development', The Amercian Economic Review, 86:4, pp. 852-873.

Romer, P. M. (1986) 'Increasing returns and Long-Run Growth', Journal of Policitcal Economy, 94:5, pp. 1002-1037.

Romer, P. M. (1987) 'Growth Based on Increasing Returns Due to Specialization', American Economic Review, 77:2, pp. 56-62.

Romer, P. (1990) 'Endogenous Technological Change', Journal of Political Economy, supplement, S71-S102.

Ru, P. Zhi, Q. Zhang,F. Zhong,X., Li,J. and Su, J. (2012) 'Behind the Development of Technology: The Transition of Innovation Modes in China's Wind Turbine Manufacturing Industry.', Energy Policy, 43, pp. 58-69.

Shah, A. (1995) 'R\&D capital, spillovers and industrial performance', in Shah, A. (Ed.) Fiscal incentives for investment and innovation, New York. Oxford University Press/ World Bank, pp. 240-243 and 247-249.

Sinton, J.E. and Fridley, D.G. (2000) 'What Goes Up: Recent Trends in China's Energy Consumption', Energy Policy, 28:10, pp. 671-687.

Sonobe, T., Hu, D. and Otsuka, K.(2002) 'Process of cluster formation in China: A casestudy of a garment town', Journal of Development Studies, 39:1, pp. 118-139.

Srikanth, N. (2008) 'Composite challenges in wind turbine application', JEC Composite, 47.

Srikanth, N. (2011) 'Material adoption practices of wind industry and its effect on product scaling trends', Proceedings of the 1st International Technology Management Conference, ITMC 2011 , art. no. 5996045, pp. 697-705.

Srikanth, N. and Funk, J. L. (2011) 'Geometric scaling and long-run reductions in cost: The case of wind turbines', Proceedings of the 1st International Technology Management Conference, ITMC 2011, art. no. 5996044, 2011, pp. 691-696.

Srikanth, N. and Watanabe, C. (2012) 'Fusing East and West Leads a Way to Global Competitiveness in Emerging Economy Source of China's Conspicuous Strength in Solar Industry', Journal of Technology Management for Growing Economies, 3:2, pp. 7-53.

Srikanth, N. and Watanabe, C. (2013) 'Government's Catalytic Role in Emerging Economy: Critical Comparison of China's Conspicuous Strength in Wind and Solar Industry', Journal of Technology Management for Growing Economies, 4:1, pp. 7-48.

Watanabe, C., Asgari, B. and Nagamatsu, A. (2003) 'Virtuous cycle between R\&D, functionality development and assimilation capacity for competitive strategy in Japan's high-technology industry', Technovation, 23:11, pp. 879 -900.

Watanabe, C. (2009) 'Technological Innovation across nations: Applied studies of coevolutionary development', Laxenburg. Springer Publications.

Wharton (2011) 'Renewable Energy in China: A Necessity, Not an Alternative', Knowledge@ Wharton,(online) Available from <URL:http://knowledge.wharton.upenn.edu/article. cfm? articleid $=2214>$.

Williamson, J.G. (1991) 'Productivity and American leadership: A review article', Journal of Economic Literature, 29:1, pp. 51-68.

Worldbank (2013) (online) (Cited 6 March 2013) Available from <URL:http://www.worldbank. org/projects/P067625/china-renewable-energy-scale-up-program-cresp $>$.

Worldbank (2014) 'IMF GDP deflator of China', (online) Available from <URL:http://data. worldbank.org/indicator/NY.GDP.DEFL.ZS>.

You, J. and Wilkinson, F. (1994) 'Competition and Cooperation: Towards an Understanding of
Fusing East and

West Leads 
Srikanth, N.

Watanabe, $\mathrm{C}$. the Industrial District', Review of Political Economy, 6:3, pp. 259-78.

Zucker, L.G., Darby, M.R., and Armstrong, J. (2004) 'Geographically localized knowledge: spillovers or markets?' in Cantwell, J. (Ed.) Globalization and the location of firms, USA. An Elgar Reference Collection, pp. 65-86.

Narasimalu Srikanth, National University of Singapore, Singapore.

Email: g0600356@nus.edu.sg.

Chihiro Watanabe, National University of Singapore and University of Jyvaskyla, Finland. Email: watanabe.c.pqr@gmail.com. 